\title{
Research on the Cultivation Strategy of Artisan Spirit and Innovation and Entrepreneurship Ability of College Students
}

\author{
Shihan Liu ${ }^{1, a}$, Ruibing Yuan ${ }^{1, b}$, Guiyin Zhang ${ }^{1, c}$, Siyuan Liu ${ }^{2, d}$, \\ Jiaxuan Wang ${ }^{1, \mathrm{e}}$, Zhou Yan ${ }^{3, \mathrm{f},{ }^{*}}$ \\ 1. School of Safety Engineering, Shenyang Aerospace University, Shenyang, 110136, China \\ 2. School of Energy and Environment Engineering, Shenyang Aerospace University, Shenyang, \\ 110136, China \\ 3. Engineering Training Center, Shenyang Aerospace University, Shenyang, China \\ a1256758764@qq.com, b2533696240@qq.com, c 2383428204@qq.com, d1435263325@qq.com, \\ e862748167@qq.com, f, *sdyanzhou16888@163.com
}

\begin{abstract}
Starting from various problems existing in college students' innovation and entrepreneurship activities, this paper explores the similarities between craftsman spirit and innovation and entrepreneurship ability, analyzes the significance of their combination for social development, and puts forward the integration of craftsman spirit and innovation and entrepreneurship in theoretical teaching, innovation and entrepreneurship practice and psychological teaching. And through some specific methods to achieve the relevant theory, improve the talent training system in colleges and universities, cultivate students' "artisan spirit", and enhance the ability of innovation and entrepreneurship.
\end{abstract}

Keywords: Craftsman Spirit; Innovation and Entrepreneurship; Personnel Training.

\section{Introduction}

Since Premier Li Keqiang put forward the term "mass entrepreneurship and innovation" in September 2014, a nationwide wave of "mass entrepreneurship and innovation" has been launched. The entrepreneurial rate of college students has also increased year by year. However, according to the survey, the average success rate of college students in China is only 5\%. Through the data, it can be shown that there are still some problems in college students' innovation and entrepreneurship, which restrict their success in innovation and entrepreneurship. In order to solve the shortcomings of students' innovation and entrepreneurship, the craftsman spirit and innovation spirit are combined from three aspects, so that the talent training in the new century is more secure.

\section{Problems of College Students' Innovation and Entrepreneurship Activities at Present}

First, there is a deviation in the understanding of innovation and entrepreneurship. Many students' understandings of innovation and entrepreneurship is only superficial. However, innovation and entrepreneurship have deep meanings. Innovation is to have a novel idea and turn it into certain benefits or to improve existing things to make them more suitable for the needs of development; Entrepreneurship is a process in which entrepreneurs optimize and integrate resources to create greater economic or social value. The deviation of college students' understanding of innovation and entrepreneurship restricts their entrepreneurial enthusiasm and hinders the concentrated expression of their personal and social values.

Second, lack of innovation and entrepreneurship awareness. Influenced by traditional ideas, Chinese parents do not support and encourage entrepreneurship, which has high risks and uncertain benefits. This kind of traditional family concept constrains students' innovative and entrepreneurial consciousness, and students lack initiative in innovation and entrepreneurship. 
Third, students' comprehensive ability is insufficient. Influenced by the Internet age, students' learning attitude is impetuous, and the existing professional knowledge is difficult to support the whole innovation and entrepreneurship activities. In addition, when students encounter difficulties, they often lack self-determination and perseverance and can't continue to work hard to maintain the operation of existing entrepreneurial activities.

Fourth, the existing education system is imperfect. At present, most universities only have theoretical teaching of innovation and entrepreneurship, but cannot provide students with a practical opportunity, so that students cannot find an available platform to combine theory with practice, and cannot really understand and carry out innovation and entrepreneurship.

\section{The Meaning of Craftsman Spirit and the Significance of its Combination with Innovation and Entrepreneurship}

The core of craftsman spirit is the quality and spirit of fine carving, striving for perfection and pursuing perfection of products. Artisan spirit and innovation and entrepreneurship have both overlap and expansion, and their integration will produce " $1+1>2 "$ effect.

First of all, under the contemporary society calling for the return of craftsman spirit, it is the general trend for colleges and universities to cultivate new talents with innovative and entrepreneurial abilities. Therefore, the effective integration of craftsman spirit in innovation and entrepreneurship will make the training of talents in the new era more secure, and become an important driving force for students to give full play to their innovative and entrepreneurial abilities. Therefore, they are highly unified and complement each other.

Secondly, the craftsman spirit is consistent with the cultivation goal of innovation and entrepreneurship. Under the general environment of the strategic deployment and development of "double innovation" in China, the country's demand for high-quality and high-skilled talents with double innovation is particularly urgent. As a national and social consensus, the craftsman spirit aims to cultivate new talents that meet China's national conditions. This kind of talents who are integrated into the craftsman spirit will have higher professional ability and comprehensive quality, and will be more easily accepted by the society.

In addition, craftsman spirit can also promote the creation of a new situation of innovation and entrepreneurship education. The current double education can't match the social needs. In the future educational practice, colleges and universities should take the craftsman spirit as the guide, actively cater to the needs of the times, change the direction of personnel training, systematically promote the reform of college education and teaching mode, build and constantly improve the new mode of double innovation education, and promote the transformation and upgrading of colleges and universities to meet the requirements of "Made in China 2025" and the era of building an industrial power.

In the near future, the cultivation strategy of integrating craftsman spirit into innovation and entrepreneurship will be driven by the social requirements in the new era. Innovative and entrepreneurial ability and craftsman spirit will also become one of the key training directions of colleges and universities in the future.

\section{Integrate Craftsmanship with Innovation and Entrepreneurship from Three Aspects}

\subsection{Artisan Spirit into Theoretical Teaching}

Integrating craftsman spirit into theoretical teaching aims to create a good spiritual atmosphere for college students to innovate and start businesses, and cultivate innovative talents for universities. First, in the process of theoretical teaching in universities, attention should be paid to the integration of ideological and political teaching. Through the interaction between teachers and students and the cultivation of humanistic quality in the process of teachers' teaching, college students' understanding 
and perception of respecting the industry and being loyal to their duties should be strengthened, and at the same time, students should have a preliminary understanding of the connotation of craftsman spirit.

Secondly, in theoretical teaching, teachers in universities should be encouraged to actively create and guide students' interests in the basic teaching process, and hands-on links should be set up in the curriculum, so that they can personally feel the collision and integration of the spirit of excellence and innovation in the production process. In the new era, the success of an innovation and entrepreneurship practice project cannot be achieved by a single person working alone and acting independently, but by teamwork, unity and cooperation. Therefore, in the process of classroom teaching, we should pay attention to the innovation of teaching methods at the same time, such as group defense, "turning over the classroom" and other forms of integrated teaching, so that students can learn to communicate and exchange with team members, cooperate and collaborate, brainstorm ideas, foster strengths and circumvent weaknesses, and give full play to the maximum benefits among teams.

Finally, activities such as homework evaluation and manual competition are interspersed in theoretical teaching, so that students can cultivate the spirit of pursuing excellence and dare to innovate in the activities and enhance the overall innovation ability of college students.

\subsection{Artisan Spirit into the Practice of Innovation and Entrepreneurship}

The specific measures to integrate the craftsman spirit into the practice of improving college students' innovation and entrepreneurship ability are as follows.

First, improve the awareness of innovation and entrepreneurship and realize the craftsman spirit. The school library can introduce a variety of innovative and entrepreneurial teaching materials, and regularly hold reading and writing activities with the theme of artisan spirit and creative spirit. In addition, the school can actively publicize the successful cases of innovation and entrepreneurship and Comrade Xi Jinping's exposition on craftsman spirit through campus radio, WeChat official account and school news, to help students cultivate their awareness of innovation and entrepreneurship.

Second, improve the innovation and entrepreneurship curriculum system. A complete innovation and entrepreneurship curriculum system is the most effective and main way to improve college students' ability of creating double talents and cultivate their craftsmanship. universities can introduce foreign excellent double-creative teaching materials or compile special double-creative teaching materials according to their own different majors, and gradually create a complete and effective teaching system through diversified teaching methods, to promote double-creative education and cultivate the craftsman spirit of college students.

Third, create a high-level team of instructors. University teachers should be composed of teachers with both professional knowledge and social practice experience. Only in this way can we teach theoretical knowledge without neglecting the teaching of practical experience. Teachers' team should fully grasp the educational methods of creating and guiding students' interests, and cultivate a keen eye for tapping the bright spots of students' personality. In this way, students' innovation and entrepreneurship education can be guaranteed to be implemented, instead of just sitting and talking.

Fourth, build a practical platform for innovation and entrepreneurship. Universities can improve students' overall comprehensive ability in many ways through the construction of real laboratories, science parks for college students, engineering training centers, and innovation bases for college students, to enhance their entrepreneurial management ability in the process of innovation and entrepreneurship. According to different objects, students' innovation and entrepreneurship ability can be promoted through different forms of practice models.

Finally, integrate craftsman spirit into campus culture construction. Universities can integrate the cultivation of craftsman spirit and innovation and entrepreneurship into the construction of campus culture, actively publicize the typical deeds and achievements of "Double Creation", and carry out competitions and theme activities to reflect and strengthen students' spirit of "Double Creation" and 
"Craftsman Spirit", so that college students can be exposed to the campus culture full of striving for progress and innovation, and truly cultivate college students with "Double Creation" and "Craftsman Spirit".

\subsection{Artisan Spirit into Psychological Teaching}

The integration of craftsman spirit into psychological teaching plays a vital role in the improvement of spiritual and cultural system in universities. Integrating artisan spirit into psychological teaching can help solve students' psychological problems, give students emotional communication and emotional counseling, lay a foundation for cultivating college students' healthy psychology and sound personality, guarantee their all-round development, and promote the perfection of the talent training system in universities. Therefore, in order to improve the psychological quality of college students, we must combine the two.

Universities can cultivate students' spirit of hard-working and teamwork, temper students' perseverance, improve students' willpower and improve their psychological quality by carrying out specific measures such as outdoor orienteering, marathon and field military activities. In addition, universities can improve students' mental health education by setting up special psychological platforms and hiring professional psychological teachers.

\section{Conclusion}

Although the innovation and entrepreneurship rate of college students in China is increasing year by year, there are always some problems in their innovation and entrepreneurship activities. In order to solve these problems, it is proposed to integrate craftsman spirit into innovation and entrepreneurship. Introducing craftsman spirit into theoretical teaching, innovation and entrepreneurship practice, and psychological teaching, strengthening students' awareness of double innovation, cultivating students' craftsman spirit, and driving universities to change talent training mode, to improve the current innovation and entrepreneurship education system, cultivate comprehensive and all-round talents, and then pave the way for social construction in the new era.

\section{Acknowledgments}

This work was financially supported by Shenyang Aerospace University Student's Platform for Innovation and Entrepreneurship Training Program fund. Project fund number:X202010143362.

\section{References}

[1] Yuan yuan, Shao nan, Xiang wenji. cultivation of college students' innovation and entrepreneurship from the perspective of craftsman spirit [J]. survey of education, 2020 (9): 25-26.

[2] Zhang Chenxi. Innovation and Entrepreneurship Education for College Students from the Perspective of Artisan Spirit [J]. Quality Development, 2019 (7): 51-52.

[3] Zhang Kailiang. Research on Improving College Students' Innovation and Entrepreneurship Ability Based on Artisan Spirit Cultivation [J]. Education Theory and Practice, 2017 (12): 23-25.

[4] Yang Jun. Some thoughts on the research path of "internet plus" innovation and entrepreneurship education integrating craftsman spirit [J]. Chinese and foreign entrepreneurs, 2019 (15): 186.

[5] Wang Jiong. Cultivation of college students' innovation and entrepreneurship ability and craftsman spirit [J]. Education Time and Space, 2020 (10): 128-130. 